\title{
The Four Ps of Creativity in the Drama/Theatre Project Jutka's Sleeplessness
}

\author{
Kamila Witerska \\ University of Humanities and Economics in Lodz, Poland \\ E-mail address: kamilawiterska@gmail.com
}

ARTICLE INFO

\section{Keywords:}

4Ps of creativity

Drama

Theatre

\section{Article history:}

Received 18 May 2018

Received in revised form 21 May 2018

Accepted 10 June 2018

ISSN: 2354-0036

DOI: $10.1515 /$ ctra-2018-0007
A B S TRACT

The text is a case study report concerning research on a drama/theatre project called Jutka's Sleeplessness that was performed in the public space of Łódź. The purpose of the research was to address the question of how this creative - new and valuable product - in the form of the drama/ theatre project Jutka's Sleeplessness was created and what aspect of creativity decides on the success of a project that combines drama with theatre. The discussion represents an attempt to demonstrate how the four Ps of creativity work in a drama/theatre project.

\section{INTRODUCTION}

Creativeness can be analysed in many different ways. One may be interested in the creative process, external factors which shape this process, in the author or in the final product emerging from the whole process. It is for this reason that we distinguish four dimensions of creativity, also known as aspects of creativity - four strands, four fundamental areas of enquiry, the four Ps of creativity or the four dimensions of creativity (Rhodes, 1961; Mooney, 1963; Jackson \& Messick, 1965, Richards, 1999).

The four Ps of creativity which were introduced over 50 years ago by Ross Mooney at the Utah Conferences on the Identification of Creative Scientific Talent have been developed as four conceptual approaches to the study of creativity. Therefore, creativity is analysed in terms of: person, process, product and press of the environment.

\section{METHODOLOGY}

This text provides a case study report of research on a drama/theatre project "Jutka's Sleeplessness" that was performed in the public space of Łódź. The purpose of the re- 
search was to address the question of how this creative - new and valuable product - in the form of the drama/theatre project "Jutka's Sleeplessness" was created. The main research problem was formulated as follows: what aspect of creativity decides on the success of a project that combines drama with theatre? More detailed questions that aim at collecting and analysing data were outlined as follows: what process is involved in making the performance? What is the role of persons responsible for the performance in developing its value and newness? What are the characteristics of the artistic product of the project? What factors stimulate and which restrain creativity during the process of making the performance in a drama/theatre project?

The initial steps in the research involved analysing the effects of the project - observing the theatre performance that was the result of a (relatively) finished project. The performance "Jutka's Sleeplessness" was staged at The New Theatre on October 31, 2017. This was followed by holding interviews with teachers/facilitators who had directed the performance and analysing the footage - interviews with students and recordings from rehearsals.

\section{RESULTS}

The drama/theatre project "Jutka's Sleeplessness" was performed in the public space of Łódź - what began as a street performance "Szpera 42", was developed at the Łódź Centre of Teacher Training and Vocational Education, at schools in Łodź and completed with a performance at The New Theatre. The project refers to the history of the city during World War II and concerns the events that took place in the Łódź Ghetto in the autumn of 1942. Horrible events happened that year - the Germans began their operation of transporting those unfit to work to extermination camps in Chełmno (Kulmhof), mostly children under 10 years of age, the elderly and sick. The operation named Wielka Szpera (Allgemeine Gehspere, General Curfew) killed 15 to 20 thousand Jews.

\section{Person}

The research conducted clearly states, that the key element of the drama/theatre project "Jutka's Slleplessness" is the teacher, theatre instructor, coach - the person who supervises the project from start to finish being at the heart, the focal point of the whole enterprise.

In the personal aspect, creativity is considered in the context of the creator's features, i.e. the features of the so-called creative personality. "These may include both ongoing trait characteristics and fluctuating state characteristics of the person" (Richards, 1999, p. 733). Creative personality traits can be considered as abilities, cognitive styles, affective and motivational patterns, intentions, attitudes and values (Richards, 1999). 
The way to determine such traits is i.a studying the biographies of famous creators and attempting to capture the set of traits that are typical of those. The following features are considered as forming the creative personality: courage, openness, inquisitiveness, independence, responsibility, engagement or persistence (Szmidt, 2013). Knowledge of the typical features of creative personality is an important subject for pedagogy, because it gives us the possibility to develop the appropriate traits in children and youth (Szymański, 1987).

The creative subject in the case of a drama/theatre project is a collective one, divided between many persons. Besides the person conducting the project, its creators are also actors building the performance, in this case the children.

The basic questions regarding the person that creates the performance concerned the leader: - what traits should a person who initiates, coordinates and successfully completes a drama/theatre project possess - and the other creators of the performance what traits are distinctive for children involved in the creation of the spectacle?

The traits required of the person conducting the project were highlighted on the basis of the interview with the leader and with persons who contributed to the project. The outcome of the interviews shows that the personality of a creative teacher, thanks to whom the project exists, can be characterised by the following traits:

\section{Inquisitiveness}

The interest in discovering the history of Wielka Szpera, encouraged Hanna JastrzębskaGzella to investigate the history and sources, and to talk to people. She stated that this story haunted and motivated her to act. The initiator of drama/theatre projects is thus characterised by inquisitiveness, that is, the drive to perceive and understand things and phenomena.

\section{Openness to experiences}

The project was born out of a single experience - participation in the street theatre performance "Szpera 42". Her interest in the subject inspired Hanna Jastrzębska-Gzella to investigate and to participate in other events and workshops relating to the story. The initiator of the drama/theatre projects is thus a person who is open to experiences, involved in other people's actions, responding to their energy and starting her own activity.

\section{Openness to people and the ability to cooperate}

The interest in the subject results in the fact, that the initiator of the project starts to talk to other people about it. Openness to people and the ability to cooperate enables cooperation with other people. She engaged in talks with facilitators from the ŁAD Association. 
The idea for cooperation was thus born between Hanna Gzella, Samuel Warpechowski and Marta Czajczyńska - teachers from special needs schools.

Their intent is to refer to the idea from 2010, when encouraged by and in cooperation with Hanna Jastrzębska-Gzella they carried out a drama/theatre project „Frédéric Chopin and his Music - educational drama". They met with students and collected resources for workshops.

\section{Overcoming limitations}

A characteristic trait of the trainer is the ability to overcome the limitations that appear in the course of the project. More so, it is the trait of accepting a challenge first and then overcoming the limitations. In "Jutka's Sleeplessness" project the trainer was presented with the challenge of involving children from the music school in the project. Hanna Jastrzębska-Gzella accepted the challenge and soon the idea arose of adding this new group to the performance. As it turned out, the children could not complete the assigned task, so together with them she searched for another way in which they could participate in the project. Eventually some of the students took part in the performance giving modern comments to the historic events, while the rest prepared an exhibition presented in the foyer.

In the "Jutka's Sleeplessness" project a number of scenes were created for a shadow theatre. These were created by the children from the special needs school, children with different limitations. In the shadow theatre the children felt safe and could participate in the performance.

The play is based on the individual potential of the people making it. It is as much based on their abilities, as on their limitations.

\section{Mindfulness of things happening in the process}

Adding people to a project that has already started reveals a very important competence of the person responsible for this drama/theatre project, that can be defined as mindfulness. The audience, initially inactive, gradually becomes involved in future performances. Thanks to this the process of repeating the performance remains fresh and is enriched every time.

The trainer for the project is not only mindful of the audience and the process of including them in the project, but also of the creators of the performance, during the process of producing the play. While building the scenes for the "Jutka's Sleeplessness" performance, two girls wanted to take the leading role, so the character of a second girl, Jutka's friend was created, to be played alongside the main character. 


\section{Flexibility}

The trainer for the drama/theatre project, Hanna Jastrzębska-Gzella, shows flexibility in thinking and acting. She easily changes her ways of thinking and approach by modifying work and tasks in favour of persons creating the performance, to match different external factors.

\section{Pursuing one's goal}

The trainer for the project is also characterised by determination in pursuing her goal, which is the driving force of the enterprise.

The co-creators of the performance in the drama/theatre project are the children. The trainer describes one of the girls as good, shy, honest, helpful, kind, delicate and sensitive. She says about one of the girls participating in the performance: "The distinguishing quality in her was her exceptional interest in what we were doing during the classes. She liked to watch other girls work, but she herself was shy". The third of the main characters was Josek, of whom Hanna Gzella says: "This boy was polite, cheerful and... he talked really, really fast. Definitely too fast to be understood."

The children's characteristics presented by Hanna Gzella show, that the participants of a drama/theatre project do not have to be bold, self-confident or go-ahead ones. Quite the opposite - these activities attract children that are shy, and for whom playing a role and the fiction itself, serve as a protective shield, thanks to which they can overcome their shyness and try out their creativity.

Hanna Jastrzębska-Gzella also talks about the parents of the children participating in the performance, pointing out the importance of their attitude towards their children's activities, the story and the form of creativity that is a drama/theatre project.

\section{Process}

"A processual understanding of creativity is focused on the specific characteristics of psychical processes, which lead to the emergence of a creative idea or serve as a component of creative behaviours" (Szmidt, 2013, p.101, the author's translation). Considering creativity in the processual aspects enables stimulating creative processes at school, because it addresses the question of what actions are responsible for generating creative thoughts, ideas, solutions. Today it is assumed, that there is no singular process, but rather many, and at the same time the mundanity of the intellectual operations taking part in the creative process is indicated (cf. e.g. Nęcka, 2001, Szmidt, 2013).

In a drama/theatre project the process is as important as the person. As one of the main features of the drama teacher is openness, so the main feature of the process is openness, too. The process of creating a drama/theatre project can be seen as an open 
one. At each stage of building the performance, new elements, other than the already existing solutions are included and new persons join the project.

Course of actions - the process of creating the drama/theatre project:

\section{Initiating the project}

A personal, single experience. The project is born out of a single, personal experience, with a strong, emotional impact, important for the person participating in it. It is an experience that gives the feeling, that one needs to do something, that one needs to spread knowledge about it, and reach the awareness of other people. A deeply rooted confidence in the importance of given knowledge and the need for spreading it initiates further actions. Here it is an experience of the teacher, who further proposes the project to the children. It is participation in a street performance. The theatre project is born out of an inspiration from another theatre project.

\section{Searching/researching sources}

The next stage is doing historical research, researching sources, finding materials for a given subject. Talks with people that inspire further action.

In the case of the project "Jutka's Sleeplessness" it was a conversation with a person who created another project related to the book by Dorota Combrzyńska-Nogala. In this way Hanna Jastrzębska-Gzella discovered the book "Jutka's Sleeplessness" and various educational materials developed by the Institute for Tolerance. She established cooperation with the Institute in disseminating an educational platform regarding the holocaust, made contact with The Marek Edelman Dialogue Centre in Łódź and took part in the "Stones speak" workshops, content of the book and started to carry them out. Hanna Jastrzębska-Gzella also incorporated a personal story, connected with the fact that the whole family from her mother's side helped to save a Jewish boy Michał. A witness of those events - 83 year-old Elżbieta Jastrzębska - Hanna Gzella's mother - was a guest during an educational part of the performance "talks with the audience".

After collecting the materials Hanna Gzella initiated drama workshops and started to make the project happen.

\section{Drama workshops}

The workshops were conducted as part of the work of the Łódź Centre of Teacher Training and Vocational Education, first at schools, and later at the Poleski Art Centre.

\section{The theatre performance}

An idea for a theatre performance was formed on the basis of the conducted workshops. Hanna Jastrzębska-Gzella began to run drama workshops on "Jutka's Sleeplessness" as part of the theatre activity at the school for visually handicapped children. During 
the drama workshops acts and characters were developed. Jastrzębska-Gzella says that this is only "playing with scenes". Children read the text first and later they acted out particular scenes. The teacher presented them with a context for the situation and later the children created a scene. The teacher wrote down the act and later there was a rehearsal. The children did not need to memorise the text, but they knew the particular scene and knew the purpose and meaning of a given situation and of the whole performance.

Theatre activities were conducted once a week. The whole process of building the performance took around three months.

Another person - a Polish language teacher - simultaneously built scenes from a shadow theatre with children from a special needs school. Together they prepared two rehearsals. After a premiere of the performance at the music high school, the students became involved in the project. At some stage a guitarist and a pianist joined in, making live music for the performance.

Here we have the creation of a performance in an unending process, adding elements, involving new persons. That way we extend the area of influence of the performance. And every person involved spreads further the knowledge on the content of that performance.

\section{Product}

Any product of human activity can be creative. Therefore we can speak of a creative essay, idea, solution or a creative dish. As stated by Richards, it can be "a concrete product, behavioural result or repertoire, set of ideas to communicate or indeed a process one is attempting to influence" (Richard, 1999, p.733)

To be named creative, the product needs to be characterised by the quality of newness and its value (cf. e.g. Nęcka, 2001; Szmidt, 2007, Góralski, 1990). The above mentioned criteria are however relative, because, what is considered new or valuable depends, for instance, on cultural and historical conditions. Besides, the product can be considered new from an individual human perspective, like objects created by children.

While discussing children's creativity, an important element of its definition should be emphasizing the aspect of value and newness of the product, at least for the creator. Additionally, an important criteria for estimating the value of creativity for pedagogy is ethics. This was accentuated by Krzysztof Szmidt who in speaking about the way pedagogy understands creativity, wrote: "In my opinion, one cannot call creative a product that is destructive, immoral, unlawful, $\backslash(\ldots)$ In that sense those products or activities are creative - to my understanding - which contribute to gaining values related to goodness and beauty and to the search for truth, implementing the ideas of tomorrow (which was often point- 
ed out by social pedagogues) into the lives of individuals and societies" (Szmidt, 2013 p. 99-100, the author's translation).

The product of the project was the performance of “Jutka's Sleeplessness". It was very varied. It contained the elements of art theatre, sound theatre, pantomime and shadow theatre. Furthermore there was another interesting feature of the performance - the large amount of children engaged in the project and joining different conventions including mixing past with present. This "patchwork" structure of the performance was an effect of including children from different schools, such as high schools, special schools, the school of music in the project and providing them with the form of participation in the performance that was right for them - safe and interesting from their point of view.

Another feature of the performance was the authenticity of the character. In interviews, the teachers confirmed my supposition that the children did not learn the text by heart, but improvised. The children knew the structure of individual scenes, but the dialogues were created live. The children improvised with the text and each other. Samuel Warpechowski even states that in the case of a drama-theatrical project, one cannot speak about a performance, but rather it is a meeting.

Drama theorists talk about theatre performance in a similar way. "A theatre piece is often regarded as a product, although it will be experienced by the audience as an event, rather than as an art object"' (O'Neill, 1995, p. XV).

The final product, the outcome of the drama/theatre project "Jutka's Sleeplessness" is the performance; however the results of the project can be seen beyond locked in time and space frames during theone hour act of presenting a play. "Jutka" - a girl who was once shy now acts as the school representative. Josek - was a child who slurred his words and the performance motivated him to practice his speech, leading to improvement. Participation in the project enabled the children to overcome their own limitations and motivated them to work on themselves and on the performance.

Additionally this project gave them the opportunity to better understand the events from the past. Those events became familiar to them. By playing their roles they became participants of those events for a moment. One of the girls playing in the performance says:

"My grandmother was in the Ghetto. Only grandmother said that she was taken away, that they found her, grabbed her and took her away, I didn't know where. They took her away, just like that. But now I know it was during that szpera." 
The children asked me: Why did this happen? Why did people treat others that way? Ola who played Jutka told us during the drama workshops:

"This is so sad, people killing other people. But people are not that different, only, well, they differ in skin colour, but what does it mean? For example cats have different fur colour, yes? So what? A cat is a cat."

Another result of the drama/theatre project is an increased interest in the subject, the number of children who want to read more, which is indicated by the fact that the first edition of the book "Jutka's Sleeplessness" by Dorota Combrzyńska-Nogala was sold out.

No one knows what the final outcome of the project will be, as new ideas and initiatives constantly appear in relation to the project. After the performance Hanna Jastrzębska-Gzella was approached by a person rescued from Łódź Ghetto. JastrzębskaGzella recorded the interview with that person and intends to incorporate this material into her next projects. She also plans to make a radio play "Jutka's Sleeplessness". She was invited to Warsaw to present the performance to young people.

In a drama/theatre project, the performance is only a relatively final product. It is a culmination of actions of the people involved in the project, but they are the ones who continue the project through their future activities. This is because of the content the project is embedded in - significant for the participants who are entirely involved.

In a drama/theatre project the learning process affects all participants, even teachers. The subjective effect for a teacher running the project is self-development and extending his/her knowledge on a given subject. As Hanna Jastrzębska Gzella says: "The person who facilitates, also learns. A teacher learns as much as children do."

\section{Influence of the environment}

Creative activity always proceeds in a specific environment, therefore the conditions under which creativity works are important and defined as the "totality of factors influencing the work, content, intensity, course and results of creative activity" (Szmidt, 2013, p. 104, the author's translation). These are trans-subjective conditions - external - relating to the social context in which creativity operates, that is material, technical, socio-cultural. They are „circumstances necessary for releasing \creative production” (Mooney, 1963, p. 332).

With regard to the positive or negative influence of external factors on creativity, they are divided into the stimulants and inhibitors of creativity. Stimulants are positive factors that influence the creative activity, reinvigorating and making the process more effective, while inhibitors have a negative influence on creativity, restraining and making the creative process more difficult (Szmidt, 2013). 
In the light of the conducted research, the main inhibitor for creativity in the case of a drama/theatre project is the curriculum. Hanna Jastrzębska-Gzella highlighted the lack of classes devoted to a drama/theatre subject in schools as the main difficulty for conducting the project. Drama activities are performed during advisory classes or as part of Polish language classes. Additional classes on drama/theatre are conducted only occasionally at schools and very few children attend them.

Furthermore, the curriculum is overloaded with information and because of that teachers are not eager to take classes to community centres. They are also not willing to devote additional time from their private lives, because these in any case are needed to keep up with the curriculum.

The postulated changes in the educational system therefore concern the modification of the curriculum through reducing theoretical knowledge in favour of more practical work for the students, involving them emotionally and intellectually.

Furthermore, a good solution would be to include classes on drama/theatre as part of Polish language classes, which would be based on required reading. It would be a good idea to include books like "Jutka's Sleeplessness" which talk about history in an accessible and child friendly manner in the school curriculum.

A stimulant of creativity in the researched project are the actions of other people, who are involved in the particular subject, and are members of the same community, who support each other. The support also comes from some families of children participating in the project. This is how Hanna Jastrzębska-Gzella described one of these families: Robert has a wonderful mother, who accepted his participation in the spectacle immediately. His big sister, mother, grandmother attended the performance. In the end they said loudly "we know what it meant for Robert to work on Jutka, how he changed, how he started to speak slowly and clearly". The family was very proud of Robert. His mother said "I did not know it was such a big enterprise!"

\section{DISCUSSION}

In the light of the conducted research, two of the four aspects of creativity - person and process seem to be more important than the other two in the drama and theatrical project.

An important feature of the teacher who leads the whole process is the openness to people and experience, the flexibility of thinking and taking emerging adversities and transforming them into challenges. Thus, it seems that the competences of the person running the project are primarily pedagogical competences, and only then those of a director.

The surprising personality feature of children who are eager to create a theatrical performance is shyness. Perhaps it is so, because taking on a role in the form of fiction is 
a mask that releases action, courage and creativity (Witerska, 2014). According to Philip Zimbardo (1990) entering into a role is a way of overcoming shyness, precisely because it is encased fiction. The person in the role has the feeling that it was not her own "I" exposed to the assessment, but the role, in addition sanctioned by the circumstances. Hence drama may provide a remedy for shyness and social anxiety, which appear to be increasing in recent years. Shyness disorganizes and severely limits social and professional activities in more than $50 \%$ of people over different periods of life. Scientists consider this increase to be the result of the development of a civilization which contributes to the growing isolation of people (Henderson, 2000; Zimbardo, 1990).

It is also interesting that the process of creating a performance in a drama-theatrical project is characterized by openness and the ability to include new people and elements at every stage of building the show. Hence, the potential of drama-theatrical projects lies in the possibility of including children with diverse educational needs in the project.

The product, which is a theatrical performance, is unpredictable, authentic and patchwork until the end. It is a meeting rather than a spectacle, experience and exploration rather than exposure.

And finally the pressure of the environment seems to be a stimulus for the project thanks to the drama teacher's skill for transforming the obstacles into challenges.

\section{REFERENCES}

Combrzyńska-Nogala, D. (2012). Bezsenność Jutki. [Jutka’s Sleeplessness]. Łódź, Literatura. Góralski, A. (1990). Być nowatorem. Poradnik twórczego myślenia. [To be an innovator. Guide to creative thinking.] Warsaw: PWN.

Henderson, L., (2000). Social Fitness. Source: Shyness.com

Jackson, P. \& Messick, S. (1965). The person, the product and the response. Conceptual problems in the assessment of creativity. Journal of Personality, 33.

Mooney, R. L. (1963). A conceptual model for integrating four approaches to the identification of creative talent. In C.W. Taylor, F. Barron (Eds). Scientific creativity: Its recognition and development. New York: Wiley.

Nęcka, E. (2001). Psychologia twórczości. [Psychology of creativity]. Gdansk: GWP.

O'Neill, C. (1995). Drama Worlds. A Framework for Process Drama, Portsmouth: NH, Heinemann.

Rhodes, M. (1961). An analysis of creativity, Phi Delta Kappan 42, 7.

Richards, R. (1999). Four Ps of creativity. In M. A. Runco, S. R. Pritzker, (Eds.) Encyclopedia of creativity. San Diego: Academic Press.

Szmidt K.J. (2007) Pedagogika twórczości. Pedagogy of creativity]. Gdańsk, GWP. 
Szmidt, K.J. (2013) Pedagogika twórczości. [Pedagogy of creativity]. Sopot: GWP.

Szymański, M.S. (1987). Twórczość i style poznawcze uczniów. [Creativity and cognitive styles of learners]. Warsaw: WSiP.

Witerska, K. (2014). Drama. Przewodnik po koncepcjach, technikach i miejscach.

[Drama. A guide to concepts, techniques and places]. Warszawa: Difin.

Zimbardo. P. (1990). Shyness: What it is, what to do about it. Da Capo Lifelong Books

Corresponding author at: Kamila Witerska, University of Humanities and Economics in Lodz, Poland, 26 Sterlinga St., 90-212 Lodz.

E-mail: kamilawiterska@gmail.com 